DOI https://doi.org/10.18551/rjoas.2018-11.01

\title{
ECONOMIC EVALUATION OF THE POTENTIAL OF RUSSIAN AGRICULTURAL ENGINEERING, PRODUCING MACHINERY AND EQUIPMENT FOR LIVESTOCK
}

\author{
Polukhin A.A., Doctor of Economics, Professor of RAS \\ Federal Research Center of Agrarian Economic and Social Development of Rural Area, \\ Moscow, Russia \\ E-mail:polukhinogac@yandex.ru
}

\begin{abstract}
The results of the research of agricultural engineering industry potential in the Russian Federation are given below, producing machinery and equipment for livestock. The analysis of the agricultural machinery market is provided in the article. The economic substance of material and technical support of agriculture is justified. The economic analysis of potential of agricultural engineering industry development in Russia is given in the article, taking into consideration a policy of import substitution and export potential extension. The main directions of the branch development are justified; the dynamic development assessment is given. The segmentation of agricultural machinery market is made from the point of view of its mastering by Russian producers. The forecast of the development of the agricultural engineering industry and the export potential is offered. The main directions of the development of the agricultural machinery market as a key element of the organizational and economic mechanism of technical modernization of the branch are determined.
\end{abstract}

\section{KEY WORDS}

Agricultural economics, equipment and material support, agricultural engineering, industry.

The modern economic situation makes it possible to state dynamic development of the Russian agricultural engineering industry in a number of market segments. First of all it is a production of energy-saturated tractors and production of the self-propelled forage combine harvesters. In this regard we consider it useful to justify export potential realization indicators of the Russian agricultural machinery producers, because modern reality dictates the need for more intensive development of the international market.

The equipment and material maintenance of agriculture is an initial link of all macro and micrologistic chains, which influence the final agricultural indicators and the efficiency of all the production and economic activities of an enterprise or an organization. Taking the above mentioned information into consideration, we have conducted the research directed at justification of the export orientation of agricultural engineering industry.

The purpose of the research is to prove the directions of agricultural engineering industry development in the Russian Federation, to estimate the export potential of the branch.

Tasks of research:

- To estimate the growth prospects of the agricultural machinery realization volume of the Russian Federation;

- To analyze the target indicators of the implementation of the Strategy of agricultural engineering industry development in Russia till 2030;

- To study the export orientation of producers of different types of agricultural machinery;

- To develop and prove target indicators of the export orientation of agricultural mechanical industry.

\section{MATERIALS AND METHODS OF RESEARCH}

The research was carried out in the context of combined researches and scientists' coordination from the Federal State Funded Research Institution of the Federal Research 
Center of All-Russian Scientific Research Institute of Agricultural Economics and the thematic plan of FASO of the Russian Federation 0569-2015-0013 "Improving the organizational and economic mechanism of equipment and material maintenance of livestock branches under the conditions of import substitution in the resource markets".

The export potential of agricultural engineering industry in the Russian Federation was the object of the research. The sources of the empirical information were the data of the official statistics and data of the All-Russian agricultural census of 2016 and data of the Ministry of Agriculture.

Mathematical and statistical data processing was carried out by means of the standard techniques of the economic analysis. The monographic method, methods of expert assessment, analysis and synthesis were used for the justification of the development directions.

\section{RESULTS OF STUDY}

Both Russian and import agricultural machinery have a number of competitive advantages when developing the market. So, for example, the main competitive advantages of the domestic agricultural machinery are low prices, service availability, possibility of selfindependent repair, protectionist policy of the state; competitive advantages of the foreign equipment are reliability and productivity. In the market of agricultural machinery the Belarusian equipment due to its low price and protectionist policy of the government of Republic of Belarus has a dominant position in the sales structure.

The forecast of updating the level of the main machinery park for 2013 - 2020 developed by us in 2014 is presented in the table 1 . Unfortunately judging by the volumes of acquisition of the new machinery the inertial scenario comes true. Speaking about the updating level we mean the number of the acquired new agricultural machinery. This forecast considers the existing tendencies, target indicators and mechanisms of the state stimulation of the machinery park modernization. However under the inertial scenario of the development we understand the variant, which doesn't presume the state correction of the level and mechanisms of the support, they will remain at the planned level. Speaking about the target scenario we mean the stepwise creation of the conditions on intensive updating of the park.

Table 1 - The volume growth prospects of the agricultural machinery realization in the Russian Federation

\begin{tabular}{|c|c|c|c|c|c|c|c|c|c|c|}
\hline \multirow{2}{*}{\begin{tabular}{|c|}
$\mathrm{n} / \mathrm{n}$ \\
$\begin{array}{c}\text { Forecast } \\
\text { option }\end{array}$ \\
\end{tabular}} & \multicolumn{3}{|c|}{ Actual data $^{1}$} & \multicolumn{4}{|c|}{$\begin{array}{c}\text { Expected scenarios of the agricultural machinery } \\
\text { market development in the Russian Federation } \\
\text { (worked out by employees of the All-Russian } \\
\text { Scientific Research Institute of Agriculture Economy, } \\
\text { published in 2014) }\end{array}$} & \multicolumn{3}{|c|}{$\begin{array}{l}\text { Expected indicators by the } \\
\text { realization of the Strategy of } \\
\text { Russian agricultural machinery } \\
\text { development industry until } 2030^{3}\end{array}$} \\
\hline & 2014 & 2015 & 2016 & 2017 & 2018 & 2019 & 2020 & 2021 & 2025 & 2030 \\
\hline \multicolumn{11}{|c|}{ Tractors } \\
\hline Inertial & \multirow{2}{*}{8595} & \multirow{2}{*}{7907} & \multirow{2}{*}{8082} & 9811 & 9929 & 10047 & 10166 & \multirow{2}{*}{12500} & \multirow{2}{*}{13370} & \multirow{2}{*}{14220} \\
\hline Target & & & & 14020 & 14840 & 15345 & 16250 & & & \\
\hline \multicolumn{11}{|c|}{ Forage combine harvesters } \\
\hline Inertial & \multirow{2}{*}{686} & \multirow{2}{*}{575} & \multirow{2}{*}{666} & 815 & 802 & 789 & 777 & \multirow{2}{*}{1060} & \multirow{2}{*}{1510} & \multirow{2}{*}{1890} \\
\hline Target & & & & 1298 & 1370 & 1445 & 1515 & & & \\
\hline \multicolumn{11}{|c|}{ Milking parlors and aggregates } \\
\hline Inertial & \multirow{2}{*}{990} & \multirow{2}{*}{1040} & \multirow{2}{*}{749} & 1213 & 1227 & 1240 & 1253 & \multirow[b]{2}{*}{$\cdots$} & \multirow[b]{2}{*}{$\cdots$} & \multirow[b]{2}{*}{$\cdots$} \\
\hline Target & & & & 1492 & 1524 & 1585 & 1602 & & & \\
\hline
\end{tabular}

\footnotetext{
${ }^{1}$ Availability of agricultural machinery and power capacities in agricultural organizations in Russian Federation in 2016. Statistics digest - Moscow: 2017.

${ }^{2}$ Polukhin A.A. Organizational and economic bases of technical reequipment of agriculture. A. Polukhin. - Orel: Kartush, 2014. - 330 pages.

${ }^{3}$ Strategy of export development in of agricultural mechanical engineering branches until 2025. - Approved in a government directive of the Russian Federation on 8/31/2017 No. 1879- $r$
} 
The Strategy of the development of the Russian agricultural machinery industry until 2030 is developed. It is approved by the order of the Government of the Russian Federation on July 7, 2017 No. 1455-r. Target indicators of this document are presented in the table 2.

Table 2 - The target indicators of the Strategy of the development of the Russian agricultural engineering industry until 2030

\begin{tabular}{|l|c|c|c|c|}
\hline \multicolumn{1}{|c|}{ Indicators } & 2017 & $\begin{array}{c}1 \text { stage } \\
2021\end{array}$ & $\begin{array}{c}2 \text { stage } \\
2025\end{array}$ & $\begin{array}{c}3 \text { stage } \\
2030\end{array}$ \\
\hline $\begin{array}{l}\text { Share of the Russian agricultural machinery production in the domestic } \\
\text { market in a total amount of agricultural mechanical machinery } \\
\text { production, \% }\end{array}$ & 56 & 80 & $\begin{array}{c}\text { Not less } \\
\text { than } 80\end{array}$ & $\begin{array}{c}\text { Not less } \\
\text { than } 80\end{array}$ \\
\hline $\begin{array}{l}\text { Ratio of export and shipments of the agricultural machinery production in } \\
\text { a domestic market, \% }\end{array}$ & 12 & 25 & 50 & $\begin{array}{c}\text { Not less } \\
\text { than } 50\end{array}$ \\
\hline Index of the agricultural machinery production, \% & 115 & 112 & 112 & 106 \\
\hline $\begin{array}{l}\text { Share of expenses volume for carrying out the research and } \\
\text { development in the total amount of the enterprises revenue in } \\
\text { agricultural machinery industry }\end{array}$ & 0,7 & 1,5 & 3 & 3,2 \\
\hline $\begin{array}{l}\text { Number of the designers working at the enterprises of agricultural } \\
\text { engineering, \% }\end{array}$ & 750 & 1000 & 1700 & 2100 \\
\hline $\begin{array}{l}\text { Share of foreign components and materials in the general prime cost of } \\
\text { the production of agricultural engineering, \% }\end{array}$ & 35 & 20 & 15 & 10 \\
\hline
\end{tabular}

The realization of the Strategy will allow creating the base for agricultural engineering industry for the efficient production under the competitive conditions on the internal and external markets. In this mechanism the main elements are agricultural producers, scientific and educational institutions, public authorities, financial institutions and the organizations of agricultural engineering industry.

The forecast for the export orientation of the agricultural engineering industry is made with the expert way, taking into account the branch development dynamics, requirements of the domestic market, the implemented mechanisms of the state support, the analysis of the market niches, indicators of the Strategy of the export development in the branches of agricultural engineering industry until 2025.

Table 3 - Number of built and modernized farms for livestock production from 2013 to $2017^{*}$

\begin{tabular}{|c|c|c|c|c|c|c|}
\hline Producers & 2013 & 2014 & 2015 & 2016 & 2017 & Total for the entire period \\
\hline \multicolumn{7}{|c|}{ Cattle to the slaughter } \\
\hline introduced a new & 41 & 39 & 60 & 41 & 68 & 249 \\
\hline reconstructed and modernized & 24 & 26 & 47 & 20 & 17 & 134 \\
\hline \multicolumn{7}{|c|}{ Dairy farm } \\
\hline introduced a new & 140 & 112 & 120 & 117 & 161 & 650 \\
\hline reconstructed and modernized & 131 & 94 & 99 & 119 & 70 & 513 \\
\hline \multicolumn{7}{|l|}{ Pigs for slaughter } \\
\hline introduced a new & 31 & 31 & 28 & 32 & 29 & 151 \\
\hline reconstructed and modernized & 8 & 6 & 2 & 6 & 11 & 33 \\
\hline \multicolumn{7}{|c|}{ Bird for slaughter } \\
\hline introduced a new & 10 & 19 & 13 & 14 & 18 & 74 \\
\hline reconstructed and modernized & 21 & 11 & 13 & 6 & 14 & 65 \\
\hline
\end{tabular}

* Data of the Ministry of Agricultural of the Russian Federation.

As can be seen from the data presented in table 1, in the Russian Federation, during the implementation of stimulating activities of the State program for the development of agriculture and regulation of markets for agricultural products, raw materials and food for 2013-2020, a significant number of new livestock facilities were built and existing ones were modernized.

In the segment "combine harvesters" "Rostselmash Combine Plant, LLC" takes the leading positions both in the Russian Federation and in the world. In this regard it is expedient to expect growth of the export orientation of its production. 
Table 4 - Increase in production of livestock products due to the introduction of new facilities, reconstruction and modernization of facilities, thousand tons*

\begin{tabular}{|c|c|c|c|c|c|c|}
\hline Producers & 2013 & 2014 & 2015 & 2016 & 2017 & $\begin{array}{l}\text { Total for the } \\
\text { entire } \\
\text { period }\end{array}$ \\
\hline $\begin{array}{l}\text { Total production of cattle for slaughter (live weight), } \\
\text { obtained through the introduction of new facilities, } \\
\text { reconstruction and modernization of facilities, thousand } \\
\text { tons }\end{array}$ & 3,5 & 8,3 & 46,2 & 6,8 & 4,8 & 69,6 \\
\hline $\begin{array}{l}\text { The total volume of milk production obtained through the } \\
\text { introduction of new facilities, reconstruction and } \\
\text { modernization of facilities, thousand tons }\end{array}$ & 179,6 & 162,1 & 234 & 232,1 & 159,4 & 967,2 \\
\hline $\begin{array}{l}\text { Total production of pigs for slaughter (live), obtained } \\
\text { through the introduction of new, reconstruction and } \\
\text { modernization of existing facilities, thousand tons }\end{array}$ & 143,4 & 148,8 & 79,9 & 138,4 & 45,4 & 555,9 \\
\hline $\begin{array}{l}\text { Total poultry production for slaughter } \\
\text { (in live weight), obtained through the introduction of new } \\
\text { and reconstruction and modernization of existing } \\
\text { facilities, thousand tons }\end{array}$ & 154,2 & 194,6 & 232 & 251,5 & 319,3 & 1151,6 \\
\hline
\end{tabular}

${ }^{*}$ Data of the Ministry of Agricultural of the Russian Federation.

Table 5 - Assessment of the export orientation of forage combine harvester producers*

\begin{tabular}{|c|c|c|c|}
\hline Producers & 2015 & 2016 & 2016 as $\%$ over 2015 \\
\hline \multicolumn{4}{|c|}{ Production } \\
\hline Russian models & 509 & 805 & 158,2 \\
\hline Including "Rostselmash Combine Plant, LLC" & 261 & 313 & 119,9 \\
\hline «Klever» company & 229 & 383 & 167,2 \\
\hline Belorussian models (assembling in the Russian Federation) & 110 & 183 & 166,4 \\
\hline Including CJSC JV «Bryanskselmash» & 110 & 183 & 166,4 \\
\hline Total production of forage combine harvesters & 619 & 988 & 159,6 \\
\hline \multicolumn{4}{|l|}{ 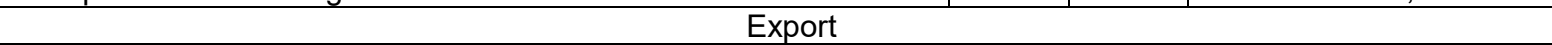 } \\
\hline Export of new forage combine harvesters & 162 & 163 & 100,6 \\
\hline - including Russian models & 126 & 141 & 111,9 \\
\hline Total export share, $\%$ & 26,7 & 16,5 & $-10,2$ percentage points \\
\hline Export share of Russian models, \% & 24,8 & 17,5 & $-7,3$ percentage points \\
\hline
\end{tabular}

*Data of the Ministry of Industry and Trade of the Russian Federation.

On the territory of the Russian Federation forage harvesters of foreign developments aren't produced (except for the Belarusian). Target indicators correspond to strategic criteria of the export development.

Table 6 - Target indicators of the export orientation of agricultural machinery industry (export share in total production), \%

\begin{tabular}{|c|c|c|c|c|}
\hline \multirow{2}{*}{ Type of machinery } & \multicolumn{2}{|c|}{ Actual data } & \multicolumn{2}{c|}{ Target indicator } \\
\cline { 2 - 5 } & 2015 & 2016 & 2020 & 2025 \\
\hline Tractors & 6,4 & 7,1 & 10,0 & 25,0 \\
\hline Grain harvesters & 17,3 & 12,2 & 25,0 & 40,0 \\
\hline Forage combine harvesters & 24,8 & 17,5 & 25,0 & 40,0 \\
\hline
\end{tabular}

The problem is that economic sanctions and anti-sanctions measures concern agricultural production and providing agrobusiness with the means of production both directly and indirectly through the change of exchange rates. Therefore the agricultural machinery production, both the Russian and foreign models with high rate of localization can be considered as one of the ways to solve the problem of the export-oriented agricultural engineering industry formation.

The offered target reference points are real and expedient proceeding from dynamics of the branch development, demand and competitive advantages of the Russian machinery in the domestic and foreign markets. 


\section{DISCUSSION OF RESULTS}

The current state of the agricultural engineering industry, level and the implemented mechanisms of the state support, strategic indicators of the branch development indicate rather a high growth potential. This growth allows to rely on the essential export orientation of the enterprise. We should note, that 31,3 thousand people are employed in the branch of agricultural engineering industry in the Russian Federation. We point out that the utilization capacity level in the agricultural engineering industry varies from $40 \%$ to $70 \%$, depending on the machinery type that presumes the high increasing potential of the production.

According to the data of 2016 the export of agricultural machinery in value terms was 7,7 billion rubles that is $163 \%$ more than in 2012 . We point out, that the Russian agricultural engineering industry has potential for export growth in the following segments of the market: combine harvesters, tractors with power more than $300 \mathrm{hp}$, soil-cultivating machinery, sowing machinery (including sowing complexes), complexes for storage and cleaning of grain, the forage towed machinery (mowers, baler, etc.).

\section{CONCLUSION}

Special attention must be paid to the realization of the principles of the foreign markets development. Tractors, combine harvesters, forage, soil-cultivating and sowing machinery produces produced by JSC Peterburgsky Tractorny Zavod, Rostselmash Combine Plant, LLC, Concern "Tractor Plants" and others can increase the production of the relevant machinery.

The realized measures of the state agricultural mechanical engineering support stimulate machinery producers to invest into the development of new models. At the same time the volumes of the investment into research and development aren't sufficient for new sales markets development therefore the growth of the state support volumes of agricultural mechanical engineering is necessary.

\section{REFERENCES}

1. Butov A.M. Market of agricultural machinery: National Research University Higher School of Economics. - 2016. p. 9-11

2. Korchevoy E.A. State and prospects of agricultural engineering development: report presentation. - Ministry of Industry and Trade of the Russian Federation. February, 2017.

3. Availability of agricultural machinery and power capacities in agricultural organizations in Russian Federation in 2016. Statistics digest - Moscow: 2017.

4. Polukhin A.A. Organizational and economic bases of technical reequipment of agriculture. A. Polukhin. - Orel: Kartush, 2014. - 330 pages.

5. Strategy of export development in of agricultural mechanical engineering branches until 2025. - Approved in a government directive of the Russian Federation on 8/31/2017 No. $1879 \mathrm{~g}$

6. Strategies of agricultural machinery development in Russia until 2030. - Approved in a government directive of the Russian Federation of July 7, 2017 No. 1455-r 